\title{
MANAJEMEN STRATEGI BAZNAS DALAM PENGELOLAAN DANA FILANTROPI ISLAM
}

\author{
Siti Mardiah (sitimardiyah_uin@radenfatah.ac.id) \\ Dosen Tetap Fakultas Ekonomi dan Bisnis UIN Raden Fatah Palembang
}

\begin{abstract}
Abstrak
Penelitian ini bertujuan untuk mengetahui manajemen strategi baznas dalam pengelolaan dana filantropi islam. Penelitian ini menggunakan metode penelitian kualitatif, dengan jenis penelitian berbentuk field research. Sedangkan teknik pengumpulan data dalam penelitian ini menggunakan beberapa teknik yaitu observasi, wawancara, dan studi pustaka. Analisis data yang digunakan pada kajian ini adalah analisis deskriptif dan analisis eksploratif. Analisis dilakukan dengan menguraikan dan mengekplorasi manajemen strategi yang telah dilakukan Baznas yang meliputi perencanaan strategi, pengimplementasian strategi dan pengevaluasian strategi. Hasil penelitian yang dilakukan Manajemen Strategi yang dilakukan Baznas meliputi perencanaan strategi, pengimplementasian strategi dan pengevaluasiaan strategi. Perencanaan strategi adalah perumusan strategi meliputi misi, visi, dan tujuan dari perusahaan, pengembangan strategi, dan pengarahan kebijakan dengan memperhatikan analisis lingkungan yang ada untuk melihat peluang dan tantangan.Implementasi strategi Baznas dilakukan dengan membuat programprogram kerja di bidang pengumpulan dan bidang pendistribusian dan pendayagunaan, bidang pendidikan dan dakwah, bidang kesehatan dan sosial kemanusiaan, bidang perencanaan, keuangan dan pelaporan, bidang Administrasi, Sumber Daya Manusia dan Umum. Sementara Evaluasi strategi adalah evaluasi terhadap program kerja yang direncanakan dan dilaksanakan Baznas dengan memperhatikan target dan sasaran kerja yang ingin dicapai
\end{abstract}

Keyword: Manajemen, Strategi, Filantrofi Islam

\section{PENDAHULUAN}

Sejak dikeluarkannya Undang-Undang No.23 Tahun 2011 tentang pengelolaan zakat bahwasanya tujuan dari pengelolaan zakat nasional yaitu meningkatkan efektivitas dan efisiensi pelayanan dalam pengelolaan zakat, dan meningkatkan manfaat zakat untuk mewujudkan kesejahteraan masyarakat dan penanggulangan kemiskinan. Untuk mencapai tujuan yang dimaksud oleh Undang-Undangtersebut, maka kelembagaan pengelola zakat harus terintegrasi dengan BAZNAS sebagai koordinator seluruh pengelola zakat, baik BAZNAS Provinsi, BAZNAS Kabupaten/Kota maupun LAZ.

Dari penghimpunan zakat yang dilakukan Baznas. Data yang diperoleh oleh Baznas pada tahun 2016 adalah sebagai berikut : 
I-Finance Vol. 4. No. 1. Juni 2018

Manajemen Strategi Baznas.......Siti Mardiyah

Tabel 1

Perolehan Zakat tahun 2016

\begin{tabular}{|l|l|l|}
\hline Institut & Penghimpunan & Persentase \\
\hline BAZNAS & $92,568,574,079$ & 2.53 \\
BAZNAS Province & $644,859,329,420$ & 17.65 \\
BAZNAS & $876,626,483,800$ & 24.00 \\
Regency/City LAZ & $2,039,218,862,993$ & 55.82 \\
\hline Total & $\mathbf{3 , 6 5 3 , 2 7 3 , 2 5 0 , 2 9 2}$ & $\mathbf{1 0 0 . 0 0}$ \\
\hline
\end{tabular}

Dari data dokumentasi Baznas tahun 2016. Zakat yang berhasil dihimpun oleh Baznas sebesar Rp.3,653,273,250,292. Institusi yang menghimpun dana ini adalah Baznas pusat, Baznas provinsi, dan Baznas kota ditambah himpunan dari berbagai Lembaga Amil Zakat. Potensi dana terkumpul dari dana ZIS sangat besar. Berdasarkan hasil riset BAZNAS dan IPB, potensi zakat secara nasional ditaksir mencapai Rp 217 triliun setiap tahun. Angka itu dilihat berdasarkan produk domestik bruto (PDB). Ketika PDB naik, maka potensi zakat juga bergerak. Hal ini didasarkan pada PDB tahun 2010. Padahal setiap tahun PDB bergerak naik. Kalau memperhitungkan pertumbuhan PDB tahun-tahun sesudahnya, maka tahun ini potensi zakat berubah menjadi sekitar Rp 240 triliun. Hal ini bermakna dana yang terhimpun baru mencapai 1,25 persen.

Untuk daerah Sumatera Selatan, berdasarkan hasil Riset BAZNAS bekerjasama dengan IPB dan IDB, secara nasional Sumatera Selatan memiliki potensi sebesar 2,88\% dari potensi secara nasional sebesar Rp. 82.793.348.705.971,50. Potensi Zakat Provinsi Sumatera Selatan sebesar Rp. 2.385.588.618.814,96 dan target penghimpunan zakat sebesar Rp.74,92 milyar yang meliputi zakat Fitrah dan Zakat Mal.Umat Islam di Sumatera Selatan dengan jumlahnya yang mayoritas muslim merupakan potensi yang sangat besar bagi zakat. Karena itu kajian ini dilakukan untuk melihat bagaimana strategi yang dilakukan Baznas Propinsi Sumatera selatan dalam mengelola dana filantropi Islam di Palembang.

\section{LANDASAN TEORI Manajemen Strategi}

Adapun kajian mengenai manajemen strategi dilakukan oleh Surjani R, penelitian ini membahas mengenai bagaimana seharusnya sebuah perusahaan dalam menghadapi era globalisasi. Sebagaimana diketahui bahwa globalisasi merupakan penyebaran inovasi ke dan dari seluruh dunia dengan penyesuaian politis dan budaya menyertainya, oleh karenanya maka setiap perusahaan memerlukan adanya sebuah manajemen strategi untuk tetap mempertahankan eksistensi di persaingan global. Beberapa temuan dari hasil penelitian ini diantaranya adalah perlunya sebuah perusahaan melakukan spesialisasi yang dilaksanakan melalui manajemen strategi seperti menggunakan analisis nasional, analisis lingkungan internal dan eksternal, strategi Internasional, dan kepemimpinan strategis.

Kajian selanjutnya mengenai manajemen strategi dilakukan oleh Sumiati, penelitian ini membahas strategi lingkungan internal dan eksternal terhadap 
kinerja lembaga, penelitian ini menemukan fakta bahwa adanya pengaruh yang signifikan dari lingkungan eksternal ke lingkungan internal, dan pengaruh signifikan lingkungan eksternal terhadap kinerja lembaga. Selain itu, lingkungan internal juga berpengaruh signifikan terhadap kinerja. Dan penelitian selanjutnya adalah dilakukan oleh Rustan. Beliau mengkaji manajemen strategi pada penataan SDM. Penelitian ini juga menganalisis hasil mix strategies dengan 6 (enam) langkah penataan sumber daya manusia. Melalui pelaksanaan strategi ini, ianya diharapkan bahwa efektivitas, efisiensi, dan profesionalisme aparatur dapat dicapai.

\section{Filantropi Islam}

Pembahasan tentang Filantropi dilakukan oleh Imron Hadi Tamin, kajian ini ini berusaha untuk mendiskripsikan bagaimana kontribusi filantropi Islam di dalam meningkatkan kesejahteraan warga desa Sukereno Kabupaten Jember. Dalam penelitian ini berhasil menemukan bahwa filantropi yang dilakukan oleh petani jeruk terhadap keluarga miskin baik yang berupa karitas maupun pemberdayaan serta penyediaan sumber-sumber produksi mempunyai kontribusi terhadap peningkatan kesejahteraan.

Ada pula kajian yang juga dilakukan tentang Filantropi dilakukan oleh Amaroh S,Amaroh membahas potensi dan kendala yang dihadapi Filantropi Islam, Islam mendudukkan filantropi sebagai bentuk amal saleh yang memiliki dampak yang luas bagi terciptanya keadilan, kesejahteraan, dan kebebasan. Dalam konteks makro ekonomi, akumulasi potensi sosial dapat menyeimbangkan sisi permintaan masyarakat. Potensi ini pada titik tertentu dapat menurunkan average propensity to consume kelompok miskin.

\section{METODOLOGI PENELITIAN}

Penelitian ini menggunakan metode penelitian kualitatif, dengan jenis penelitian berbentuk field research. Sedangkan teknik pengumpulan data dalam penelitian ini menggunakan beberapa teknik yaitu observasi, wawancara, dan studi pustaka dengan penjelasan sebagai berikut;

1. Observasi

Teknik ini dilakukan dengan cara mengamati dan mencatat secara teliti keadaan dan berbagai kegiatan yang berlangsung di BAZNAS-Prov. di kota palembang.

2. Wawancara

Wawancara dilakukan secara bertahap kepada keseluruh pengurus BAZNASProv. yang menjadi sampel dalam penelitian ini.

3. Dokumentasi

Dokumentasi adalah mencari data mengenai perencanaan, pengimplementasian dan pengevaluasiaan strategis yang sudah dilakukan Baznas pada tahun 2016.

4. Studi kepustakaan

Studi kepustakaan yaitu proses pengumpulan data yang berbentuk referensi ilmiah maupun untuk mendapatkan berbagai penelitian terdahulu tentang topik yang sama atau menyerupai dengan penelitian ini. 
Analisis data yang digunakan pada kajian ini adalah analisis deskriptif dan analisis eksploratif. Analisis dilakukan dengan menguraikan dan mengekplorasi manajemen strategi yang telah dilakukan Baznas yang meliputi perencanaan strategi, pengimplementasian strategi dan pengevaluasian strategi.

\section{PEMBAHASAN}

Manajemen strategi merupakan suatu seni atau teknik atau ilmu yang merumuskan, mengimplementasikan, mengevaluasi serta mengawasi berbagai keputusan fungsional organisasi bisnis maupun non bisnis yang dipengaruhi lingkungan internal dan eksternal,sehingga memberikan kemampuan kepada organisasi untuk mencapai tujuan yang diharapkan. Adapun yang menjadi proses manajemen strategi adalah perumusan formulasi strategi, implementasi strategi, dan evaluasi strategi.

\section{Perumusan Strategi}

Formulasi strategi merupakan pengembangan perencanaan jangka panjang untuk manajemen yang efektif melalui analisis lingkungan. Termasuk juga didalamnya terdapat misi, visi, dan tujuan dari perusahaan, mengembangkan strategi, dan pengarahan kebijakan.

Analisis lingkungan merupakan sebuah proses monitoring terhadap lingkungan organisasi yang bertujuan untuk mengidentifikasikan peluang (opportunities) dan tantangan (threads) yang mempengaruhi kemampuan organisasi untuk mencapai tujuannya. Analisis lingkungan digunakan pada perencanan-perencanaan strategi untuk memantau lingkungan dalam menentukan peluang atau ancaman.

Dalam dinamika pembangunan dan kesenjangan ekonomi yang terjadi di Indonesia, serta geliat ekonomi syariah yang mulai menemukan momentumnya dan iklim inklusi dalam sektor keuangan, zakat memiliki peranan yang cukup krusial. Ada empat peran yang dilakukan zakat dalam pembangunan ini, yaitu: memoderasi kesenjangan sosial, membangkitkan ekonomi kerakyatan, mendorong munculnya model terobosan dalam pengentasan kemiskinan, dan mengembangkan sumber pendanaan pembangunan kesejahteraan umat di luar APBN maupun APBD.

a. Pertama, peran moderasi kesenjangan sosial yang dapat dilakukan oleh zakat tampak secara konkret dalam distribusi harta dari para wajib zakat (muzaki) kepada orang yang berhak menerima zakat (mustahik), dengan amil zakat sebagai perantara. Dengan redistribusi harta non-transaksional ini, zakat secara teoritik dapat mengurangi kesenjangan kemakmuran antara golongan kaya dan golongan miskin. Implementasi zakat secara benar diyakini dapat mengurangi ketimpangan ekonomi yang ada selama ini.

b. Kedua, peran kebangkitan ekonomi kerakyatan merupakan agenda zakat yang secara bahasan bermakna tumbuh dan berkembang. Penyaluran zakat kepada mustahik memiliki agenda untuk meningkatkan kemampuan mereka dalam men-cukupi kebutuhan hidupnya, baik yang dalam bentuk pendistribusian zakat yang bersifat karitatif maupun pendayagunaan zakat yang bersifat produktif. Memberdayakan mustahik merupakan agenda 
memberdayakan ekonomi masyarakat miskin, membangkitkan ekonomi kerakyatan.

c. Ketiga, zakat memiliki peran dalam mendorong munculnya model terobosan dalam pengentasan kemiskinan. Program penanggulangan kemiskinan yang ada selama ini merupakan program belas kasih dari pemerintah kepada orang-orang miskin. Program penanggulangan kemiskinan dari pemerintah sangat bergantung pada keberpihakan pemerintah dalam upaya peningkatan keadilan dan kesejahteraan sosial. Berbeda dengan zakat yang merupakan syariat wajib yang harus ada dalam kehidupan. Dengan demikian, zakat memiliki kerangka filosofi yang lebih jangka panjang dan dengannya diharapkan mampu mendorong munculnya model terobosan dalam pengentasan kemiskinan yang berkelanjutan.

d. Keempat, zakat merupakan sumber pendanaan pembangunan kesejahteraan umat di luar APBN maupun APBD. Jika selama ini program penanggulangan kemiskinan sangat bergantung pada kucuran dana pemerintah, maka sejatinya, ummat Islam di Indonesia memiliki potensi dana 286 triliun rupiah setiap tahunnya yang dapat dipergunakan secara spesifik bagi kelompok orang yang tidak berdaya dalam 8 ashnaf (kategori) mustahik. Jika dapat dioptimalkan, maka potensi dana zakat ini dapat menjadi pelengkap agenda program penanggulangan kemiskinan dengan sinergi pada program pemerintah yang sedang dijalankan.

Dalam undang-undang pengelolaan zakat nomor 23 tahun 2011, disebutkan bahwa pengelolaan zakat dapat dilakukan oleh BAZNAS yang merupakan lembaga nasional. Baznas adalah lembaga pemerintah nonstruktural yang bersifat mandiri dan bertanggung jawab kepada Presiden melalui Menteri. Dalam melaksanakan tugasnya, BAZNAS menyelenggarakan fungsi perencanaan, pelaksanaan, pengendalian pengumpulan, pendistribusian, dan pendayagunaan zakat serta pelaporan dan pertanggungjawaban pelaksanaan pengelolaan zakat.

Dalam melaksanakan tugas dan fungsinya, BAZNAS provinsi, dan BAZNAS kabupaten/kota dapat membentuk UPZ pada instansi pemerintah, badan usaha milik negara, badan usaha milik daerah, perusahaan swasta, dan perwakilan Republik Indonesia di luar negeri serta dapat membentuk UPZ pada tingkat kecamatan, kelurahan atau nama lainnya, dan tempat lainnya.

Undang-undang ini dipertegas oleh Peraturan Pemerintah nomor 14 tahun 2014 bahwa yang termasuk UPZ adalah lembaga negara, kementerian/lembaga pemerintah non kementerian, badan usaha milik negara,perusahaan swasta nasional dan asing, perwakilan republik indonesia di luar negeri, kantor perwakilan negara asing/lembaga asing masjid negara. Baznas provinsi dan baznas kabupaten juga bisa membentuk UPZ. UPZ itu meliputi kantor satuan kerja pemerintah daerah/lembaga daerah kabupaten/kota, Kantor instansi vertikal, Badan usaha milik negara atau daerah, Perusahaan swasta nasional atau daerah, Masjid / mushalla / langgar / surau, Perguruan tinggi dan sekolah/madrasah atau lembaga pendidikan lainnya, kecamatan atau nama lainnya, desa/kelurahan atau nama lainnya. 
Dalam mentranslasikan undang undang ini, Baznas sumsel telah melakukan analisis lingkungan baik secara internal dan eksternal, maka dirumuskanlah bahwasanya visi lembaga ini adalah "Menjadi pusat pengumpulan dan pendayagunaan zakat, infaq dan shadaqah untuk pemberdayaan dan kesejahteraan umat di Indonesia".

Sementara misi yang akan dijalankan untuk mencapai visi yang disepakati adalah sebagai berikut :

a. Membina kesadaran umat untuk menjadi muzakki, yang gemar berinfaq dan bershadaqah

b. Mengoptimalkan pengumpulan Zakat Infaq dan Sodaqoh serta pendistribuan yang tepat guna

c. Melakukan pemberdayaan kepada kaum dhu`afa melalui pemberian keterampilan dan dukungan modal

d. Melaksanakan kajian untuk pengembangan dan peningkatan kualitas pengelolaan zakat

e. Menuju budaya sadar zakat di Sumatera Selatan .

Tujuan dari lembaga ini adalah meningkatkan efektivitas dan efisiensi pelayanan dalam pengelolaan zakat, dan meningkatkan manfaat zakat untuk mewujudkan kesejehteraan masyarakat dan penanggulangan kemiskinan. Beberapa strategi yang termaktub dalam uraian rencana strategis Baznas Sumsel dirumuskan untuk mencapai visi dan misi yang telah disepakati. Adapun strategi yang dijalankan pada tahun 2016 ini adalah sebagai berikut :

a. Pembangunan visi bersama dan penataan infrastruktur kelembagaan zakat.

b. Standarisasi sistem kelembagaan, keamilan, perencanaan dan penganggaran, pengumpulan, pendistribusian dan pendayagunaan, standarisasi pengendalian, pelaporan dan pertanggungjawaban, standarisasi informasi manajemen dan standarisasi sumberdaya manusia, serta sistem pengawasan.

c. Muzakki-oriented service sistem dan mustahik-oriented service system

d. Akuntabilitas organisasi dan pelayanan zakat

e. Menerapkan sistem manajemen kerja yang nyaman, produktif dan terintegrasi.

f. Bekerjasama dengan seluruh komponen masyarakat; seperti organisasi masyarakat, organisasi profesi dan tokoh masyarakat/alim ulama untuk meningkatkan kesadaran masyarakat berzakat dan meningkatnya hasil pengumpulan ZIS yang optimal.

g. Melakukan inovasi dan pengembangan teknik-teknik pengumpulan ZIS dan penyalurannya, sehingga kepercayaan masyarakat terhadap BAZNAS semakin meningkat.

\section{Implementasi Strategi}

Implementasi strategi adalah sebuah proses dimana strategi dan kebijakan diarahkan kedalam tindakan melalui pengembangan program,anggaran, dan prosedur. Proses ini memerlukan perubahan dalam budaya,struktur, dan sistem manajemen pada seluruh organisasi atau perusahaan. 
Implementasi strategi Baznas dilakukan dengan membuat programprogram kerja di bidang pengumpulan dan bidang pendistribusian dan pendayagunaan, bidang pendidikan dan dakwah, bidang kesehatan dan sosial kemanusiaan, bidang perencanaan, keuangan dan pelaporan, bidang Administrasi, Sumber Daya Manusia dan Umum. Adapun program-program kerja itu adalah sebagai berikut :

a. Program Kerja Bidang Pengumpulan

Pengumpulan zakat dilakukan terhadap fitrah dan harta yang terkena zakat sebagaimana dalam Undang-undang nomor 23 tahun 2011. Adapun harta yang terkena zakat ada 9 macam yaitu emas perak dan logam mulia lainnya, uang dan surat berharga lainnya,perniagaan, pertanian perkebunan dan kehutan, petenakan dan perikanan, pertambangan, perindustrian, pendapatan dan jasa, dan terakhir harta Rikaz. Sistem pengumpulan dilakukan langsung ke pengurus Baznas atau setiap bulan dikumpulkan melalui UPZ-UPZ yang ada. Selain zakat, infaq dan sodaqoh yang dikumpulkan, baznas juga menerima dana sosial keagamaan lainnya. Sasaran yang ingin dicapai pada bidang pengumpulan zakat adalah meningkatnya kesadaran dan kepercayaan masyarakat untuk menunaikan zakat, infak dan shadaqah melalui Baznas. Indikator-indikator yang ingin dicapai pada bidang pengumpulan adalah sebagai berikut :

1) Ada peningkatan jumlah UPZ,

2) Ada peningkatan hasil pengumpulan zakat,

3) Ada peningkatan jumlah muzakki, munfiq, dan mutashoddiq.

4) Ada peningkatan nilai nominal zakat, infak dan shadaqah yang terkumpul.

Baznas pusat, Baznas Provinsi, dan Baznas Kabupaten/Kota melakukan koordinasidengan Kantor Perwakilan Indonesia di luar negeri, Satuan Kerja Perangkat Daerah, Badan Usaha Milik Negara (BUMN), serta Badan Usaha Milik Daerah (BUMD), sehingga pengumpulan zakat dapat lebih terukur sesuai dengan potensi yang ada. Sementara kebijakankebijakan yang akan dijalankan adalah memperluas jaringan informasi tentang zakat dan kegiatan Baznas, meningkatkan mutu layanan Baznas, kampanye gerakan budaya sadar zakat.

Untuk memperlancar tugas Baznas dalam mencapai tujuan sebagai lembaga filantrofi maka dalam pelaksanaannya terdapat berbagai macam program, seperti menyusun strategi pengumpulan zakat melalui sebagai berikut :

1) Pelayanan jemput zakat oleh petugas (kolektor) yang ditunjuk khusus oleh Baznas.

2) Membentuk Tim Fundraising (Penghimpunan dana ZIS).

3) Membentuk UPZ-UPZ baru dan memantau serta membina UPZ yang telah ada.

4) Meregistrasikan data Muzakki dan menerbitkan Nomor Pokok Wajib Zakat (NPWZ).

5) Memperluas jaringan kerjasama dengan pihak terkait untuk meningkatkan pengumpulan dana ZIS. 
6) Membuat peta dan data base Muzakki/munfiq dan mutashaddiq.

Lebih dari itu, untuk meningkatkan penghimpunan dana filantropi baznas juga memiliki sejumlah program yang bersentuhan langsung dengan masyarakat umum, seperti melakukan pengelolaan dan pengembangan data muzaki, melakukan kampanye budaya sadar zakat, melakukan dan mengendalikan pengumpulan zakat, meningkatkan efektifitas dan pelayanan terhadap muzaki, melakukan evaluasi pengelolaan pengumpulan zakat, menyusun pelaporan dan pertanggungjawaban pengumpulan zakat, melakukan penerimaan dan tindak lanjut komplain atas layanan muzaki, dan mengkoordinasi pelaksanaan pengumpulan zakat tingkat provinsi.

b. Program Kerja Bidang Pendistribusian dan Pendayagunaan

Pendistribusian zakat dilakukan kepada 8 asnaf zakat sesuai dengan ketentuan syariah berdasarkan skala prioritas dengan memperhatikan prinsip pemerataan, keadilan dan kewilayahan. Selain zakat yang ada langsung didistribusikan, zakat juga dapat didayagunakan untuk usaha-usaha produktif.Sasaran yang ingin dicapai pada bidang pendistribusian dan pendayagunaan adalah pendistribusian dana zakat infaq dan sadaqoh secara tepat sasaran, cepat pendistribusiaannya, memenuhi rasa keadilan, sesuai dengan kebutuhan masyarakat dan sesuai ketentuan syari'ah.

Dalam aspek pendistribusian dan pendayagunaan, penyaluran zakat perlu untuk melakukan sinergi di antara organisasi pengelola zakat (OPZ) baik bersifat teknis di tingkat pelaksanaan program maupun pada tataran pertukaran data dan informasi mengenai mustahik yang berhak menerima zakat. Tujuan dari sinergitasini adalah agar tidak ada lagi mustahik yang mendapatkan bantuan zakat berganda, sementara di wilayah lain masih banyak mustahik yang belum terbantu oleh manfaat zakat. Dalam hal ini, BAZNAS memiliki peran yang sangat penting untuk memoderasi kesenjangan sosial melalui penyaluran zakat yang terintegrasi secara nasional

Indikator yang digunakan sebagai ukuran tercapainya program adalah adanya pendistribusian dan pendayagunaan dana zakat infaq dan sadaqoh terutama bagi fakir dan miskin. Selain itu, adanya pendistribusian yang sifatnya sesaat, kemashlahatan umum dan kepentingan lainnya juga merupakan indikator tercapainya program. Dalam hal kebijakan, baznas melakukannya dengan penyusunan strategi pendistribusian dan pendayagunaan zakat melalui pembuatan peta data mustahik dan database mustahik, melaksanakan pengelolaan dan pengembangan data mustahik. Baznas juga melakukan dan mengendalikan pendistribusian dan pendayagunaan zakat.

Skala prioritas dilakukan pada penyaluran zakat, infaq dan sodaqoh sesuai dengan asnab zakat adalah sebagai berikut

1) Fakir Miskin dialokasikan sebesar $40 \%$ dan penyaluran dikonsentrasikan kepada Program Bidang Ekonomi, Pendidikan dan Dakwah, serta Kesehatan dan Sosial Kemanusiaan. 
2) Muallaf dialokasikan sebesar $11,5 \%$ dan penyaluran dikonsentrasikan kepada Program Bidang Ekonomi, Pendidikan dan Dakwah serta Bidang Kesehatan dan Sosial Kemanusiaan.

3) Fisabilillah dialokasikan sebesar 13,5\% dan penyaluran dikonsentrasikan kepada Program Bidang Pendidikan dan Dakwah, Bidang Kesehatan dan Sosial Kemanusiaan serta Penambahan operasional kantor.

4) Ibnu Sabil dialokasikan sebesar $12,5 \%$ dan penyaluran dikonsentrasikan kepada Bidang Kesehatan dan Sosial Kemanusiaan.

5) Riqab dialokasikan sebesar 5\% dan penyaluran dikonsentrasikan kepada Bidang Kesehatan dan Sosial Kemanusiaan.

6) Gharim dialokasikan sebesar 5\% dan penyaluran dikonsentrasikan kepada Bidang Kesehatan dan Sosial Kemanusiaan.

7) Amil dialokasikan sebesar $12,5 \%$ dan pemanfaatan dana dikonsentrasikan kepada Belanja Pegawai serta Operasional Kantor.

Kebijakan dari Baznas adalah menggunakannya sebagai penambah dana operasional kantor serta sistem penunjang manajemen Baznas. Sebagai bagian dari manajemen, Baznas juga melakukan evaluasi pengelolaan pendistribusian dan pendayagunaan zakat, menyusun pelaporan dan pertanggungjawaban pendistribusian dan pendayagunaan zakat, serta melakukan koordinasi pelaksanaan pendistribusian dan pendayagunaan zakat tingkat provinsi.

Bentuk-bentuk penyaluran dapat dikategorikan ke dalam lima program yaitu Sumsel Sehat, Sumsel Cerdas, Sumsel Makmur, Sumsel Taqwa dan Sumsel Peduli. Program Sumsel Sehat dialokasikan kepada fakir, miskin, muallaf dan gharim sebanyak 10\%. Program Sumsel Cerdas diperuntukkan kepada fakir, miskin, muallaf sebanyak 15\%. Program Sumsel Makmur diperuntukkan kepada fakir, miskin, muallaf, fisabilillah, Riqab, Gharim sebnyak 25\%. Program Sumsel Taqwa diperuntukkan fakir, miskin, muallaf, fisabillah sebanyak 20\%. Program Sumsel Peduli diperuntukkan kepada Ibnu Sabil, Riqab dan Gharim sebanyak 30\%.

Program kerja bidang pendistribusian dan pendayagunaan meliputi proker-proker di bidang ekonomi, bidang pendidikan dan dakwah serta bidang kesehatan dan sosial kemanusiaan. Adapun program kerja itu adalah sebagai berikut :

1) Bidang Ekonomi

a) Zakat Community Development, Desa Binaan dan KBZ

Program Zakat Community Development, Desa Binaan, dan Kelompok Binaan Zakat adalah proses jangka panjang dengan mengintegrasikan program-program yang bertujuan untuk mengatasi masalah kesehatan, pendidikan, ekonomi dan masalah sosial, dengan menggunakan dana Zakat Infak Shodaqoh, Program ini dilakukan dengan metode pendekatan yang komprehensif, seperti pendekatan kelompok masyarakat yang teroganisir yang memiliki kesamaan aktivitas, pendekatan lokasi sebagai sasaran program dengan permasalahan secara geografis dan kependudukan serta pendekatan 
wilayah. Sasaran program ini meliputi masyarakat : perkotaan, pedesaan, dan pesisir.

Adapun yang menjadi prinsip dari program ini didasarkan pada berbagai hal seperti sebagaimana berikut:

- Profit, yang berarti program ini memiliki nilai keuntungan material dan non material.

- Continueyang berarti program ini berlaku untuk jangka panjang dengan target kemandirian.

- Multipiler efek yang berarti program memiliki efek multiganda terhadap aspek kehidupan masyarakat dan saling keterkaitan.

- Partisipasipatory yang berarti melibatkan secara langsung individu dan masyarakat dalam tahapan proses perencanaan sampai pelaksanaan, sebagai pelaku (subyek) dengan melibatkan pendamping. Dana ZIS merupakan sumber dana stimulan untuk membantu masyarakat dalam upaya pemenuhan kebutuhan

Adapun yang menjadi tujuan dari program ZCD adalah menciptakan iklim yang memungkinkan potensi masyarakat dapat berkembang. Peran strategis dari masyarakat sangat dioptimalkan untuk menciptakan kemandirian inisiatif dan partisipasi lebih diutamakan dalam menghadapi situasi dan permasalahan yang ada. Tujuan lainnya adalah untuk memperkuat potensi yang dimiliki masyarakat (empowering) meliputi langkah-langkah nyata yang menyangkut penyediaan berbagai peluang yang dapat membuat masyarakat menjadi semakin berdaya.

Program ini membuka peluang kemitraan dan usaha untuk mendukung proses Comunity Development. Dalam proses pemberdayaan harus dicegah agar yang lemah tidak menjadi bertambah lemah, karena kurang berdaya dalam menghadapi yang kuat. Pemberdayan juga bermakna melindung. Hal ini harus dilihat sebagai upaya untuk mencegah terjadinya persaingan yang tidak seimbang, akibat eksploitasi kelompok. Pengoptimalan peran ZIS yang dihimpun oleh lembaga amil di suatu wilayah sebagai salah satu jaring pengaman untuk mustahik, menjadi bagian pengembangan baitul maal. Rencana proyeksi program ZCD akan dilakukan dibeberapa tempat yaitu sebagai berikut:

- Desa Teluk Payo Kabupaten Banyuasin

- Desa Pian Raya Kabupaten Musi Rawas

- Desa Mendah Kabupaten OKU Timur

- Desa Gunung Megang Luar Kabupaten Muara Enim

- Kelurahan Margorejo Kota Lubuk Linggau

- Desa Selibar Kecamatan Pagaralam Utara Kota Pagaralam

- Desa Karya Mulya Kota Prabumulih, dan

- Tambahan 27 lokasi sasaran yang dibagi disetiap Kabupaten/Kota sebanyak 2 lokasi kecuali didesa sasaran ZCD hanya diproyeksikan satu lokasi di setiap satu kabupaten. 
b) Baitul Qiradh BAZNAS (BQB)

Baitul Qiradh BAZNAS (BQB) adalah lembaga keuangan mikro syariah yang berfungsi menyalurkan dana Zakat Infaq dan Sodaqoh secara produktif. Program ini bisa berupa pinjaman kebajikan (Al Qardhul Hasan) maupun melalui pembiayaan kepada para mustahik. Visi dari program kerja ini adalah menjadi lembaga keuangan mikro syariah dalam meningkatkan nilai tambah secara berkelanjutan bagi usaha mikro para mustahik. Adapun misi yang akan dijalankan pada program ini adalah

- Mendidik dan meningkatkan kemampuan wirausaha mustahik (Entrepeneurship Development Program)

- Meningkatkan pendapatan mustahik agar dapat mampu memenuhi kebutuhan hidupnya secara mandiri

- Mengubah mustahik menjadi muzaki

Rencana proyeksi program BAITUL QIRADH BAZZ akan dilakukan dibeberapa tempat yaitu sebagai berikut:

- BAITUL QIRADH BAZZ AM 954 yang berlokasi di Jalan Dr M. Isa No.38 Kel. Kuto Batu (Pasar Kuto) Palembang

- BAITUL QIRADH Masjid Jami’ Adha Perumnas Sako

- BAITUL QIRADH Masjid Taqwa Perumnas Sako

- BAITUL QIRADH Masjid Nurul Huda Kertapati

- BAITUL QIRADH Masjid Al Hidayah Plaju

2) Bidang Pendidikan Dan Dakwah

Pada bidang pendidikan dan dakwah ada empat program yang dilakukan yaitu Bina santri, Satu Keluarga Satu sarjana, bina mualaf dan dakwah radio. Tujuan dari program-program ini adalah memberikan nilai pendidikan sekaligus sebagai bentuk dakwah dari Baznas

a) Program Bina Santri

Kegiatan Bina Santri merupakan kegiatan dalam bidang Pendidikan yang memberikan beasiswa kepada siswa tingkat MTs Sederajat dan MA Sederajat yang berprestasi yang berasal dari keluarga tidak mampu. Dana yang dipergunakan untuk pembiayaan bersumber dari dana Zakat dan Infaq. Pembiayaan meliputi biaya kebutuhan hidup dan kebutuhan pendidikan di sekolah umum. Rencana proyeksi programBina Santri akan dilakukan dibeberapa tempat yaitu antaranya Forum Rumah Tahfidz Kiyai Marogan , PPA Jami'atul Qurra Palembang, Rumah Tahfidz Lantabur, Ponpes Aulia Cendekia, MTs Negeri 2 Model Palembang, MAN 2 Palembang, MA Alfatah Palembang, dan MTs dan MA Patra Mandiri Palembang

b) Program Satu Keluarga Satu Sarjana (SKSS)

Program Satu Keluarga Satu Sarjana (SKSS) adalah Program pemberian Beastudi Mahasiswa berprestasi di kampus negeri di seluruh Indonesia. Sesuai namanya program ini mengutamakan mahasiswa yang berasal dari keluarga tidak mampu tanpa sarjana. Beastudi SKSS membiayai mahasiswa semester pertama sampai 
selesai. SKSS adalah program beasiswa ikatan dinas kepada setiap penerima untuk menjadi sarjana pelopor pemberdayaan masyarakat di desanya.

Program ini bertujuan untuk mendidik lulusan SMA/MU/SMK/Ponpes yang lulus USMPTN dan terdaftar di PTN regional SKSS. Program ini juga dilakukan agar peserta memiliki kepedulian sosial serta memiliki keinginan untuk pemberdayaan potensi lokal daerah, siswa dengan nilai tambah non-akademis yang dilengkapi dengan surat keterangan atau sertifikat, perguruan Tinggi yang bermitra dengan BAZNAS dalam Program SKSS.

c) Program Bina Muallaf

Program Bina muallaf merupakan pembinaan keagamaan bagi para muallaf yang baru memeluk agama Islam. Program ini dijalankan dengan menggunakan dana Zakat dan Infaq dalam bentuk pembinaan aktivitas ibadah sosial keagamaan. Para muallaf diberikan juga bantuan modal usaha melalui Program Baitul Qiradh. Rencana proyeksi program Bina Mualaf akan dilakukan dibeberapa tempat yaitu Muallaf Center Sumatera Selatan dan Bina Muallaf An Naziat

d) Program Media Dakwah Radio BAZNAS

Program ini merupakan salah satu kegiatan yang bersifat syi'ar dakwah pengelolaan zakat. Program ini merupakan media informasi BAZNAS yang disediakan bagi para pengurus BAZNAS se Sumatera Selatan dan para amil untuk mensosialisasikan BAZNAS secara kelembagaan. serta media sosialisasi Zakat infaq dan Shadaqah melalui media radio. Rencana proyeksi program media dakwah radio baznas akan dilakukan di Radio BAZZ AM 954 dan Radio Streaming www.bazzradio.com

3) Bidang Kesehatan Dan Sosial Kemanusiaan

Pada bidang ini ada beberapa program yang bertujuan pada sosial kemanusiaan. Program-program pada bidang ini antara konter layanan mustahik dan program tanggap bencana.

a) Program Konter Layanan Mustahik

Konter Layanan Mustahik (KLM) adalah tempat pelayanan mustahik yang dibentuk BAZNAS untuk memudahkan mustahik mendapatkan bantuan sesuai kebutuhannya. Bantuan yang disalurkan PPM berbentuk hibah, yakni pemberian cuma-cuma, yang disalurkan untuk perorangan maupun lembaga.

Konter Layanan Mustahik memberikan pelayanan kepada mustahik dengan prinsip cepat, tepat dan akurat. Konter Layanan Mustahik berlokasi di Kantor BAZNAS PROVINSI SUMSEL, J1. Jenderal Sudirman No. 7490, Palembang. Buka setiap hari kerja mulai pukul 08.00 pagi sampai dengan pukul 16.00 sore.

Dana Zakat Infaq dan Sodaqoh merupakan bentuk kepedulian yangdisalurkan berbentukbantuan kebutuhan hidup Mustahik, seperti; bantuan kesehatan (bantuan pengobatan jalan), santunan pendidikan yang bersifat umum, bantuan ibnu sabil (bantuan untuk orang 
terlantar), bantuan Gharimin, bantuan mualaf,bantuan fisabilillah, bantuan advokasi pelayanan pendidikan, kesehatan dll.

b) Program Tanggap Bencana

Program Tanggap Bencana adalah sebuah program untuk merespon dan memberikan bantuan kepada masyarakat yang tertimpa musibah sesaat setelah terjadi bencana. Program Tanggap Bencana meliputi tanggap darurat, evakuasi, recovery, dan rekontruksi, pelaksanaan kegiatan Tanggap Darurat Bencana dilakukan maksimal 14 hari.

Program Tanggap Bencana dilakukan bekerjasama dengan instansi pemerintah terkait penanggulangan bencana yang tersebar di 16 kabupaten kota dan berbagai lembaga sosial. Dengan sistem kemitraan, Program Tanggap Bencana dapat dilaksanakan sesegera mungkin, setelah terjadinya bencana.

4) Bidang Perencanaan, Keuangan Dan Pelaporan

Sasaran dari program ini adalah agar menjadi pusat perencanaan program dan pengembangan jaringan mitra BAZNAS, menjadikan BAZNAS Provinsi sebagai Pusat Koordinasi Zakat Nasional di Sumatera Selatan, dan menjadikan budget control keuangan dan penyajian pelaporan keuangan BAZNAS.

Untuk mencapai sasaran tersebut, maka kebijakan yang dilakukan oleh baznas adalah dengan memfasilitasi dan membuat road maping tentang kondisi Baznas seProvinsi Sumatera Selatan, mengkoordinir dan memfasilitasi Baznas daerah seSumatera Selatan dalam rangka pengembangan organisasi, menyelenggarakan rapat kerja Baznas setingkat provinsi, dan menyajikan pelaporan keuangan pengelolaan Zakat Infaq Sadaqoh secara akuntabel dan komprehensif. Adapun yang menjadi program dari bidang ini adalah sebagai berikut:

a) Menyiapkan penyusunan rencana strategis pengelolaan zakat provinsidengan;

b) Mengadakan pelatihan pengelolaan zakat bagi pengurus Baznas.

c) Menyelenggarakan Rapat Kerja Baznas setingkat Provinsi

d) Mengadakan kajian rutin tentang zakat dan Baznas

e) Melakukan studi banding.

f) Membuat road maping data pengelolaan Zakat Infaq Sadaqoh dalam wilayah Sumatera Selatan

g) Melakukan sosialisasi, membuka saluran konsultasi zakat di Media Massa, penerbitan Bulletin, brosur-brosur dan membuat iklan himbauan berzakat melalui media elektronik, stiker dan spanduk.

h) Menyusun rencana tahunan Baznas provinsi;

i) Melaksanakan evaluasi tahunan dan lima tahunan rencana pengelolaan zakat provinsi;

j) Melakukan pengelolaan keuangan Baznas provinsi dengan pengembangan aplikasi keuangan SiMBA;

k) Melaksanakan sistem akuntansi Baznas provinsi melalui aplikasi Sistem Informasi Manajemen Baznas (SIMBA); 
1) Pengelolaan Media Informasi Baznas baik cetak maupun elektronik m)Menyusun Laporan Keuangan dan Laporan Akuntabilitas Kinerja Baznas provinsi; dan

n) Menyiapkan penyusunan laporan pengelolaan zakat tingkat provinsi.

5) Bidang Administrasi, Sdm Dan Umum

Sasaran yang ingin dicapai pada program ini adalah terwujudnya pelayanan pengelolaan zakat yang nyaman, terprogram dan terintegrasi didukung oleh sarana yang lengkapserta menjadikan sarana dan fasilitas teknologi sebagai media sosialisasi pengelolaan dan pengembangan zakat di Sumatera.

Indikator keberhasilan program ini adalah menetapkan sejumlah indikator yaitu kesekretariatan yang nyaman dan representatif, tenaga kesekretariatan yang terampil, rapi, ramah dan cepat tanggap, penataan dan pengelolaan administrasi kesekretariatan yang terpadu, dan berfungsi sebagai pusat administrasi dokumen kesekretariatan .

Dalam mencapai sasarannya, maka perlu dibuat kebijakan yang berfungsi sebagai haluan kerja. Adapun kebijakan tersebut adalah; Penataan Ruang Kerja yang ideal dan nyaman, pengendalian dan pusat control inventaris kantor dan ATK, memperbaiki dan menambah perlengkapan pendukung administrasi kantor, mengatur dan menyiapkan kebutuhan rapat, mengadakan dan mengikuti Pelatihan Amil, dan mengatur jadwal Rapat masing-masing BidangdanBagian.Adapun program yang dijalankan oleh bidang ini adalah sebagai berikut:

a) Menyusun strategi pengelolaan Amil BAZNAS provinsi

b) Melakukan perencanaan Amil BAZNAS Provinsi;

c) Melakukan rekrutmen Amil BAZNAS Provinsi;

d) Melakukan pengembangan Amil BAZNAS Provinsi.

e) Melakukan administrasi perkantoran BAZNAS Provinsi.

f) Menyusun rencana strategi komunikasi dan hubungan masyarakat BAZNAS provinsi.

g) Pelaksanaan strategi komunikasi dan hubungan masyarakat BAZNAS Provinsi.

h) Pengadaan, pencatatan, pemeliharaan, pengendalian, dan pelaporan asset BAZNAS Provinsi, dan

i) Pemberian rekomendasi pembukaan perwakilan LAZ berskala nasional di Provinsi.

6) Evaluasi Strategi

Evaluasi Strategi dilakukan terhadap implementasi strategi yang telah dilakukan dalam membuat program-program kerja di bidang pengumpulan dan bidang pendistribusian dan pendayagunaan, bidang pendidikan dan dakwah, bidang kesehatan dan sosial kemanusiaan, bidang perencanaan, keuangan dan pelaporan, bidang Administrasi, Sumber Daya Manusia dan Umum.

a) Bidang pengumpulan

Sistem pengumpulan dilakukan langsung ke pengurus Baznas atau setiap bulan dikumpulkan melalui UPZ-UPZ yang ada. Selain zakat, 
infaq dan sodaqoh yang dikumpulkan, Baznas juga menerima dana sosial keagamaan lainnya. Dari hasil pengumpulan tahun 2016 berbanding tahun 2015 adalah sebagai berikut :

Tabel 2

Laporan Posisi Keuangan Baznas

\begin{tabular}{|l|l|c|r|}
\hline No & \multicolumn{1}{|c|}{ Aktivitas Operasional } & Tahun 2015 & \multicolumn{1}{|c|}{ Tahun 2016 } \\
\hline 1 & Zakat melalui UPZ & 1.816 .448 .878 .20 & 2.194 .347 .367 .42 \\
\hline 2 & Zakat Perseorangan & 273.796 .250 .00 & 473.120 .312 .00 \\
\hline 3 & $\begin{array}{l}\text { Bagi Hasil Penempatan } \\
\text { Dana Zakat }\end{array}$ & 31.422 .826 .00 \\
\hline & Jumlah Penerimaan zakat & 2.090 .245 .128 .20 & 2.698 .890 .505 .42 \\
\hline
\end{tabular}

\begin{tabular}{|l|l|r|r|}
\hline 1 & Infaq melalui UPZ & 247.547 .473 .00 & 240.881 .995 .00 \\
\hline 2 & Infaq perorangan & 7.168 .500 .00 & 6.536 .000 .00 \\
\hline 3 & $\begin{array}{l}\text { Bagi Hasil Penempatan } \\
\text { dana infaq }\end{array}$ & 6.552 .431 .00 \\
\hline & Jumlah Penerimaan infaq & 254.715 .973 .00 & 253.970 .426 .00 \\
\hline & Total Penerimaan & 2.344 .961 .101 .20 & 2.952 .860 .931 .42 \\
\hline
\end{tabular}

Sumber : Laporan Posisi Keuangan periode 2016

Pada bidang pengumpulan dilakukan terhadap dana zakat dan infaq. Pengumpulan dua dana ini dipisahkan secara jelas karena terkait pada bidang penyalurannya. Pengumpulan zakat baik melalui 150 UPZ ataupun perseorangan tahun 2016 mengalami peningkatan sebanyak Rp.2.194.347.367.42 berbanding tahun 2015 sebanyak Rp.1.816.448.878.20 untuk Zakat melalui UPZ. Sementara zakat peseorangan tahun 2016 Rp.473.120.312.00 meningkat di banding tahun 2015 Rp.273.796.250.00. Pada tahun 2016 ada tambahan dana bagi hasil penempatan dana zakat sebanyak Rp.31.422.826.00. Sehingga penerimaan zakat pada tahun 2016 meningkat menjadi Rp.2.698.890.505.42. Peningkatan ini terjadi sebanyak $25 \%$ dari tahun 2015 sebesar Rp.2.344.961.101.20.

Pada bidang pengumpulan yang menjadi evaluasi adalah sebenarnya terjadi peningkatan pengumpulan hanya pada dana zakat, sedangkan dana infaq justru mengalami penurunan dari tahun sebelumnya.. Peningkatan dana zakat pun peningkatan hanya sekitar Rp.577.222.551.22 murni dari pengumpulan, sementara Rp.31.422.826.00 di dapat dari bagi hasil investasi penempatan dana zakat. Sebaliknya pada dana infaq justru pada tahun 2016 mengalami penurunan pengumpulan berbanding tahun 2015 sebanyak Rp.7.297.978

Pada sisi peningkatan jumlah muzzaki tahun 2016 dibanding tahun 2015 mengalami peningkatan dari 11.264 orang kepada 12.818 orang. Sementara penerima zakat, mustahiknya 4.661 orang pada tahun 2015 kepada 5.108 orang pada tahun 2016. 
b) Bidang pendistribusian dan pendayagunaan

Sasaran yang ingin dicapai pada bidang pendistribusian dan pendayagunaan adalah pendistribusian dana zakat infaq dan sadaqoh secara tepat sasaran, cepat pendistribusiaannya, memenuhi rasa keadilan, sesuai dengan kebutuhan masyarakat dan sesuai ketentuan syari'ah.Program kerja bidang pendistribusian dan pendayagunaan meliputi proker-proker di bidang ekonomi, bidang pendidikan dan dakwah serta bidang kesehatan dan sosial kemanusiaan.

Tabel 4.2

Laporan Posisi Keuangan Baznas

\begin{tabular}{|c|c|c|c|}
\hline No & Aktivitas Operasional & Tahun 2015 & Tahun 2016 \\
\hline 1 & Bidang Ekonomi & 77.000 .000 .00 & 17.600 .000 .00 \\
\hline 2 & Bidang Pendidikan dan Dakwah & 770.487 .500 .00 & 1.024 .203 .000 .00 \\
\hline 3 & $\begin{array}{l}\text { Bidang Kesehatan dan Sosial } \\
\text { Kemanusian }\end{array}$ & 533.927 .100 .00 & 216.340 .000 .00 \\
\hline \multirow[t]{2}{*}{4} & $\begin{array}{l}\text { Bidang operasional, amil pelaksana } \\
\text { dan UPZ }\end{array}$ & 353.240 .465 .94 & 360.067 .822 .16 \\
\hline & $\begin{array}{l}\text { JUMLAH PENYALURAN DANA } \\
\text { ZAKAT }\end{array}$ & 1.734 . & 1.618 .210 .822 .16 \\
\hline 1 & Sosialisasi dan edukasi & 23.030 .000 .00 & 73.280 .548 .00 \\
\hline 2 & Penyaluran dana infaq produktif & 41.909 .309 .00 & \\
\hline 3 & $\begin{array}{l}\text { Beban Operasional, Amil UPZ dan } \\
\text { Pelaksana }\end{array}$ & 47.357 .255 .62 & 121.906 .122 .00 \\
\hline 4 & Pengembangan Kapasitas Keamilan & & 19.000 .000 .00 \\
\hline \multirow[t]{2}{*}{5} & $\begin{array}{l}\text { Pengadaan Asset } \\
\text { kendaraan dai }\end{array}$ & & 46.640 .000 .00 \\
\hline & $\begin{array}{l}\text { JUMLAH PENGGUNAAN DANA } \\
\text { INFAQ }\end{array}$ & 112.296 .564 .62 & 260.826 .670 .00 \\
\hline
\end{tabular}

Sumber : Laporan Posisi Keuangan periode 2016

Pada bidang ekonomi, program kerja yang dilaksanakan tentang program ZCD dan Baitul qiradh. Pada tahun 2016, dana yang terserap pada bidang ini sebanyak 77.000.000. pada tahun 2015, sementara tahun 2016 hanya terserap 17.600.000.Program ZCD yang telah dilakukan pada tahun 2016 ada di dua tempat yaitu Desa Teluk Payo Kabupaten Banyuasin dan Desa Mendah Kabupaten OKU Timur. Sementara programBaitul Qiradh yang telah terealisasi dan masih tetap aktif ada di dua tempat BAITUL QIRADH Masjid Nurul Huda Kertapatidan BAITUL QIRADH Masjid Al Hidayah Plaju. Sementara BAITUL QIRADH BAZZ AM 954 yang berlokasi di Jalan Dr M. Isa No.38 Kel. Kuto Batu (Pasar Kuto) Palembang sekarang mengalami kevakuman.

Dari hasil wawancara dengan wakil ketua 2 Baznas menyatakan bahwasanya program pendistribusian dan pendayagunakan zakat telah dilakukan sebagaimana yang telah di 
instruksikan dari pusat. Program pendayagunaan zakat melalui Baitul Qiradh adalah satu bentuk pemberian zakat produktif berupa pemberian pinjaman dengan aqad qardul hasan.

"Baitul Qiradh yang ada agak sulit untuk dipantau kan karena kita kan menitipkan uang melalui baitul qiradh untuk diberikan kepada mereka mereka itukan para mustahiq yang ada di tengahtengah pasar itu dengan modal 2 juta, paling tidak mereka sudah tidak terikat lagi dengan rentenir, mereka sudah mengalihkan modal mereka ke baitul qiradh walaupun tidak terlalu banyak."

Menurut salah satu wakil ketua Baznas meskipin Baitul Qiradh telah dilaksanakan di beberapa tempat.Secara kualitas pelaksanaannya tetap harus dievaluasi seperti kalau selama ini pemberian modal baru sejumlah 2 juta perorang, kedepannya mungkin pemberian modal bisa di banyak jumlah modalnya berbanding orang yang menerima, akan lebih nampak hasil yang diharapkan.

Bidang pendidikan dan dakwah mempunyai programBina Santri yang telah dilakukan di Rumah Tahfidz Lantabur. Sementara program pemberian Beastudi Mahasiswa yang berprestasi berjumlah 100 orang. Sementara muallaf juga diberikan bantuan modal usaha melalui Baitul Qiradh yang dilakukan di Muallaf Center Sumatera Selatan.

Program radio Baznas mensosialisasikan Baznas secara kelembagaan. serta media sosialisasi Zakat infaq dan Shadaqah melalui media radio. Program media dakwah radio baznas pernah dilakukan di Radio BAZZ AM 954 sementara di Radio Streaming www.bazzradio.commengalami kevakuman.

Penyerapan dana di bidang pendidikan dan dakwah tahun 2016 mengalami peningkatan sebanyak Rp.1.024.203.000 sementara tahun 2015 hanya sebanyak Rp.770.487.500. Hal ini mengalami peningkatan sebesar 33\% yaitu sebanyak Rp.253.715.500.

Pada bidang kesehatan dan sosial kemanusiaan, program yang telah dilaksanakan yaitu konter layanan mustahik dan program tanggap bencana. Dana yang telah diserap pada bidang ini sebanyak Rp.216.340.000 pada tahun 2016, sementara itu dana yang diserap tahun 2015 yaitu sebanyak Rp.533.927.100.

Sementara pada beban operasional, amil pelaksana dan UPZ dana yang terserappada tahun 2016 sebesar Rp.360.067.822 yang diperuntukkan dalam program-program kerja bidang perencanaan, keuangan dan pelaporan serta bidang administrasi, SDM dan Umum

Zakat, Infaq dan Sodaqoh yang terkumpul melalui Baznas didistribusikan kepada yang berhak menerimannya dan dilakukan sesuai dengan ketentuan syariah. Pendistribusian dana zakat dilakukan kepada 8 asnaf berdasarkan persetujuan Dewan Pertimbangan BAZ Provinsi, sejak tahun 2008 hingga sekarang pembagian distribusi adalah sebagai berikut:

- Fakir/Miskin + Riqob + Gharimin diberikan sebanyak $60 \%$ 
I-Finance Vol. 4. No. 1. Juni 2018

Manajemen Strategi Baznas.......Siti Mardiyah

- Sabilillah + mualaaf diberikan sebanyak $25 \%$

- Ibnu Sabil diberikan sebanyak $12,5 \%$

- Amil diberikan sebanyak $12,5 \%$ berikut:

Implikasi kebijakan tersebut dalam program terealisasi sebagai

- Program Sumsel Sehat yang diperuntukkan untuk asnaf fakir, miskin, muallaf dan gharim diberikan sebanyak $10 \%$

- Program Sumsel Cerdas yang diperuntukan untuk asnaf fakir, miskin, mualaf, fisabilillah, gharim diberikan sebanyak $15 \%$

- Program Sumsel Makmur yang diperuntukkan untuk asnaf fakir,miskin, muallaf,fisabilillah, riqob dan gahrim sebanyak $25 \%$

- Program Sumsel Peduli yang diperuntukkan untuk asnaf fakir, miskin, ibnusabil diberikan sebanyak $30 \%$

- Program sumsel TAQWA yang diperuntukkan untuk asnaf fakir, miskin,ibnusabil diberikan sebanyak $20 \%$

Menurut Bapak Idham S.Ag. Kepala bidang pendistribusian dan pendayagunaan zakat. Penyaluran dana zakat telah diupayakan 75 $\%$ untuk kegiatan produktif. Bidang pendidikan dan pengembangan ekonomi yang banyak melakukan kegiatan produktif. memang belum nampak manfaat nya, tapi mudah-mudahan dengan pengalaman yang ada,sekarang alhamdulilah Tahun 2016 ada beberapa mustahiq yang sudah mengajukan modal usaha sekitar 15 orang yang kita bantu gerobak, alhamdulillah sudah terlaksana.

Pemberdayaan ekonomi dan dua pendidikan, itu yang paling kami dorong sekarang ini, memang tidak nampak 2 - 3 tahun memang tidak nampak, tapi tunggulah $7-8$ tahun kedepan kalau anak itu sudah jadi sarjana, ekonomi nya sudah termanage, tidak bisa langsung bolak balik karena memang modal nya sedikit, kecuali kalau aku memberikan 100 juta kepada kamu mungkin bisa itu langsung nampak, tapi kan tidak adil, kita kan ada asas pemerataan, artinya apa kalau misalnya ada 1000 orang mustahiq yang akan dibantu ya paling tidak $1 \%$ dari itu nah itu yang kita dorong sekarang ini, nah kita pelan pelan juga sekarang kan baitul qiradh sudah menaikan dengan menyesuaikan kebutuhan mereka 5 juta, 3 juta, berapa juta jadi sedikit demi sedikit mereka bisa bantu dan keberhasilanya pun bertahap.

\section{KESIMPULAN}

Manajemen Strategi yang dilakukan Baznas meliputi perencanaan strategi, pengimplementasian strategi dan pengevaluasiaan strategi. Perencaan strategi adalah perumusan strategi meliputi misi, visi, dan tujuan dari perusahaan, pengembangan strategi, dan pengarahan kebijakan dengan memperhatikan analisis lingkungan yang ada untuk melihat peluang dan tantangan.Implementasi strategi Baznas dilakukan dengan membuat program-program kerja di bidang pengumpulan dan bidang pendistribusian dan pendayagunaan, bidang pendidikan dan dakwah, bidang kesehatan dan sosial kemanusiaan, bidang perencanaan, keuangan dan pelaporan, bidang Administrasi, Sumber Daya Manusia dan Umum. 
Sementara Evaluasi strategi adalah evaluasi terhadap program kerja yang direncanakan dan dilaksanakan Baznas dengan memperhatikan target dan sasaran kerja yang ingin dicapai

\section{DAFTAR PUSTAKA}

AB Susanto, (2005), Manajemen Strategik Komprehensif, Jakarta, Penerbit Erlangga, hlm. 252

Abu Zahrah, Syaikh Muhammad, At-Takaful Al-Ijmati'i fi al-Islam, Dar al-Fikr al-Arabi, Kairo, TT, h. 62-63

Amaroh S (2014), Filantropi Islam di Indonesia : Potensi dan Kendala, Jurnal ADDIN, vol. 2, issue 1

Amipradhana, Pradhika. (2010). Perancangan Sistem Pengukuran Kinerja dengan Menggunakan Metode Balanced Scorecard pada PT. Nusa CiptaSarana. Surabaya : Tugas Akhir Teknik IndustriITS, Institut Teknologi Sepuluh Nopember.

Aris Munandar, Satrio. (2008). KetidaklogisanCara Mengukur Prestasi Kerja di Media TV. Diakses pada tanggal 16 Februari 2017.

Bukik. (2007). Mencegah Perasaan Negatif dengan SOAR. Diakses pada tanggal 1 Januari2011. http://bukik.com/2007/06/30/mencegah-perasaan-negatifdengan-soar/Government, Australian. (2006). Performance Indicator Resource Catalogue Version 1.2.

Cooperrider, David. L, Diana Whitney, Jacqueline M. Stavros, Appreciative Inquiry Handbook for Leaders of Change, Crown Custom Publishing Inc., 2nd Edition, 2008.

Cooperrider, David L\& Diana Whitney. (1999) Appreciative Inquiry, Dalam Holman, P\&Devane, T (Eds,), Collaborating for Change. San Francisco, CA; Berrett-Koehler Publisher, Inc

Fred R.David (2004), Manajemen Strategis, (edisi Indonesia), Jakarta, PT. Indeks Kelompok media,

Husein Umar (1999), Riset Sumber Daya Manusia, Jakarta, PT. Gramedia PustAKA utama, hlm 86

Imron Hadi Tamin(2011), "Peran Filantropi Dalam Pengentasan Kemiskinan Di Dalam

Jaribah bin Ahmad al-Haritsi, Fikih Ekonomi Umar bin Al-Khattab, Penerbit Khalifa,Jakarta, 2003, h..308-317

Komunitas Lokal", Jurnal Sosiologi Islam, Vol. 1, No.1. Universitas Udayana.

Kurniawati. Kedermawanan Kaum Muslimin, Potensi, Realita Zakat Masyarakat Indonesia. Jakarta, Pustaka Adina, 2004. h.5

Latief, Melayani Umat: Filantropi Islam dan Ideologi Kesejahteraan Kaum Modernis (Jakarta: Gramedia, 2010), h.33-34

Mike. (2007). Evaluasi Kinerja Produser dalam rangka Peningkatan Kualitas Program Acara Televisi pada PT. Pasific Televisi Anugerah Manado. Bitung: Tugas Akhir Jurusan Manajemen STIE Petra Bitung.

Mulyadidan Setyawan. (1999). Sistem Perancangan dan Pengendalian Manajemen: Sistem Pelipat Ganda Kinerja Perusahaan. Jakarta : Salemba Empat. 
I-Finance Vol. 4. No. 1. Juni 2018

Manajemen Strategi Baznas.......Siti Mardiyah

Mulyadi. (2001). Balanced Scorecard. Jakarta : Salemba Empat.Neely, A. (1995). Performance Measurement Design : A Literature. Cambridge : University of Cambridge Research Group.

Pratt, Julie. (2010). SOAR West Virginia : Strategic Thinking for a World-Class Early Childhood Development System. Diakses pada tangga 12 Oktober2017. http://ontheridgeline.com/downloads/ strategic_report. 061710.pdf

Prihatna, Andi Agung. Filantropi Dan Keadilan Sosial Di IndonesiaDalam Chaider S. Bamualim (Editor). Revitalisasi Filantropi Islam : Studi Kasus Lembaga Zakat Dan Wakaf Di Indonesia. Jakarta : Pusat Bahasa Dan Budaya UIN Dan The Ford Foundation. 2005, h.23

Rinaldo, Dicky. (2011). MenentukanRating Program Televisi. Diakses pada tanggal 20 Februari2011. http://www.dickyrinaldo.co.tv/ 2011/01/ menentukan -rating-program-televisi.html

Riwanti, Nindita. (2010). Evaluasi dan Perancangan Ulang Key Performance Indicator (Kpi) Warehouse PT Nestle Indonesia Kejayan Pasuruan. Surabaya : Tugas Akhir Teknik Industri ITS, Institut Teknologi Sepuluh Nopember.

Siahaan, Sitimawan D. (2002). Perancangan Sistem Pengukuran Kinerja PT. Omega Plastik dengan Menggunakan Metode Balanced Scorecard. Surabaya : Tesis Teknik Industri ITS, Institut Teknologi Sepuluh Nopember.

Sudewo, Pengelolaan Zis dan wakaf di Singapura, Serial Wakaf, 1 Juli 2008.

Surjani R, (2003), Manajemen strategi dalam menghadapi era globalisasi, Jurnal Unitas, vol. 11, issue 1

Sumiati (2014) "Strategi Internal Dan Eksternal Dalam Meningkatkan Kinerja Koperasi Di Jawa Timur", Jurnal Media Mahardhika Vol. 12 No. 3 Mei

Siti Khairunnisa Humairoh, (2009), Analisa Kelayakan Bisnis Petshopbox Studio Dan Kaitannya Dengan Pendekatan Appreciative Inquiry, Thesis. Binus University, Jakarta

Will danStron, Suzanne. (2001). The Performance Handbook : Establishing and Integrated Performance Measurement System. Diakses pada tanggal20 Februari2017. http://www.orau.gov/Pbm

Yuwono, Sony. (2003). Petunjuk Praktis Penyusunan Balanced Scorecard : Menuju Organisasi yang Berfokus pada Strategi. Jakarta : PT. Gramedia Pustaka Utama 